\title{
Abnormal High-Frequency Burst Firing of Cerebellar Neurons in Rapid-Onset Dystonia-Parkinsonism
}

\author{
Rachel Fremont, ${ }^{\star}$ D. Paola Calderon, ${ }^{*}$ - Sara Maleki, and Kamran Khodakhah \\ Dominick P. Purpura Department of Neuroscience, Albert Einstein College of Medicine, Bronx, New York 10461
}

Loss-of-function mutations in the $\alpha 3$ isoform of the $\mathrm{Na}^{+} / \mathrm{K}^{+}$ATPase (sodium pump) are responsible for rapid-onset dystonia parkinsonism (DYT12). Recently, a pharmacological model of DYT12 was generated implicating both the cerebellum and basal ganglia in the disorder. Notably, partially blocking sodium pumps in the cerebellum was necessary and sufficient for induction of dystonia. Thus, a key question that remains is how partially blocking sodium pumps in the cerebellum induces dystonia. In vivo recordings from dystonic mice revealed abnormal high-frequency bursting activity in neurons of the deep cerebellar nuclei (DCN), which comprise the bulk of cerebellar output. In the same mice, Purkinje cells, which provide strong inhibitory drive to DCN cells, also fired in a similarly erratic manner. In vitro studies demonstrated that Purkinje cells are highly sensitive to sodium pump dysfunction that alters the intrinsic pacemaking of these neurons, resulting in erratic burst firing similar to that identified in vivo. This abnormal firing abates when sodium pump function is restored and dystonia caused by partial block of sodium pumps can be similarly alleviated. These findings suggest that persistent high-frequency burst firing of cerebellar neurons caused by sodium pump dysfunction underlies dystonia in this model of DYT12.

Key words: basal ganglia; cerebellum

\section{Introduction}

Dystonia is the third most common movement disorder after essential tremor and Parkinson's disease (Stacy, 2006). A hallmark of this disorder is pathological cocontraction of agonist and antagonist muscle pairs, which causes patients to adopt abnormal postures (Phukan et al., 2011). Dystonia can be caused by genetic alteration (Müller, 2009; Schmidt and Klein, 2010), metabolic insult (Schneider et al., 2012), or injury (Bhatia and Marsden, 1994; Schneider and Bhatia, 2010) to the brain. The most common dystonias are idiopathic, although in some cases they are found to be familial and therefore are likely to have a genetic component (Fletcher et al., 1990; Waddy et al., 1991; Phukan et al., 2011). Unlike other common neurological disorders, only a minority of inherited dystonias are accompanied by overt pathological abnormalities (Breakefield et al., 2008; Bragg et al., 2011; Standaert, 2011; Paudel et al., 2012), suggesting that abnormal physiology may underlie these disorders.

Loss-of-function mutations in ATP1A3, the gene coding for the $\alpha 3$ isoform of the $\mathrm{Na}^{+} / \mathrm{K}^{+}$ATPase (sodium pump), have been shown to be associated with rapid-onset dystonia parkin-

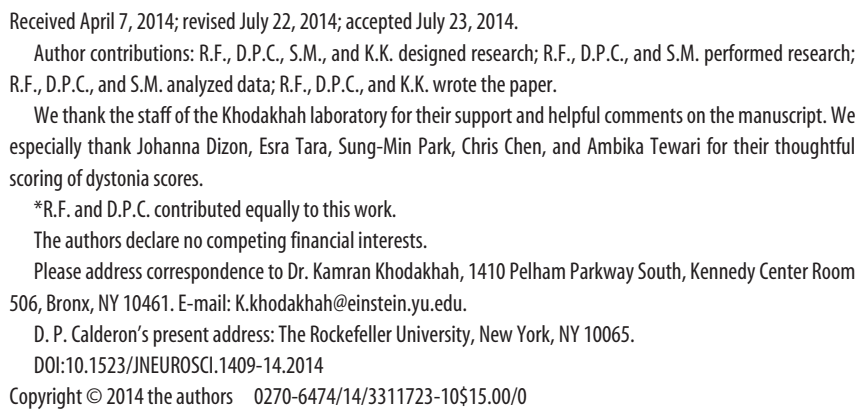

sonism, otherwise referred to as DYT12 (de Carvalho et al., 2004; Brashear et al., 2007). DYT12 is a rare disorder characterized by the abrupt onset of severe and often permanent dystonia and parkinsonism-like symptoms after a stressful event (Brashear et al., 2007). Recently, a rodent model of DYT12 that recapitulated dystonic symptoms by partially blocking sodium pumps with low concentrations of ouabain was generated (Calderon et al., 2011). In the model, infusion of ouabain to both the cerebellum and basal ganglia was required to replicate all of the salient aspects of DYT12, with the basal ganglia contributing primarily to parkinsonian symptoms and the cerebellum to dystonia. In this model of DYT12, cerebellar dysfunction was necessary and sufficient to induce dystonia (Calderon et al., 2011). Changes in the cerebellum have been identified in dystonic patients for a number of years and more recent studies suggest that some patients with inherited dystonias have altered cerebellar function (Eidelberg et al., 1998; Argyelan et al., 2009; Carbon et al., 2013). In the DYT12 model, abnormal cerebellar EEG signals were shown to correlate with dystonic bouts (Calderon et al., 2011). However, there is little known regarding the neuronal basis of cerebellar dysfunction in this model. The purpose of this study was to address this knowledge gap.

Neurons of the deep cerebellar nuclei (DCN) provide the main output of the cerebellum and project to diverse regions of the brain. They receive projections from fibers entering the cerebellum and from Purkinje cells, which are thought to be the principal computational units and sole output of the cerebellar cortex. We find that both neurons of the DCNs and Purkinje cells exhibit abnormal high-frequency bursting activity in dystonic animals, providing a specific electrophysiological signature of cerebellar dystonia in the DYT12 model. Furthermore, our re- 
sults suggest that these activity changes are most likely driven by Purkinje cells.

\section{Materials and Methods}

Experiments were performed on 8-10-week-old C57BL/6 male mice and juvenile Wistar rats of either sex (12-21 d old) in accord with the guidelines set by Albert Einstein College of Medicine.

In vitro electrophysiology. Rats were deeply anesthetized with isoflurane and decapitated. The brain was extracted from the skull and sagittal cerebellar slices $300 \mu \mathrm{m}$ thick were sectioned in ice-cold artificial CSF [ACSF; (in mm) $125 \mathrm{NaCl}, 2.5 \mathrm{KCl}, 26 \mathrm{NaHCO} 3,1.25 \mathrm{NaH}_{2} \mathrm{PO}_{4}, 1$ $\mathrm{MgCl} 2,1 \mathrm{CaCl} 2,10$ glucose 10 , pH 7.4 when gassed with $5 \% \mathrm{CO}_{2} / 95 \%$ $\mathrm{O}_{2}$ ). Slices were incubated at $35^{\circ} \mathrm{C}$ for $1 \mathrm{~h}$ and were subsequently kept at room temperature. For recordings, slices were placed in a chamber maintained at $35^{\circ} \mathrm{C}$ on an upright microscope (Zeiss) and perfused at a rate of $1.5 \mathrm{ml} / \mathrm{min}$ with ACSF containing kynurenic acid ( $5 \mathrm{~mm}$ ), picrotoxin $(100 \mu \mathrm{M})$, and GABAB receptor antagonist CGP55845 (1 $\mu \mathrm{M})$ to block synaptic transmission. Extracellular recordings were obtained from single Purkinje cells or cerebellar nuclei neurons from all nuclei using a homemade differential amplifier and glass pipette electrodes filled with ACSF. Data were sampled at $10 \mathrm{kHz}$ using an analog-to-digital converter (National Instruments) and analyzed and acquired using custom LabView software.

In vivo electrophysiology. Mice were implanted with a pump infusing either saline (controls) or ouabain into the cerebellum (see below). Also, an aluminum L-shaped bracket was fixed onto the skull with bone screws and dental cement. In the same surgery, a recording chamber was drilled in the skull on top of the cerebellum, surrounded with dental cement and covered with surgical foam and bone wax. Single-unit neural activity was recorded extracellularly using a carbon fiber electrode $(0.4-1.2 \mathrm{M} \Omega$; Kation Scientific) $\sim 2-4 \mathrm{~d}$ after surgery, at which time animals treated with ouabain exhibited dystonia. The electrode was advanced into the cerebellum until either the Purkinje cell layer or DCN was reached. Purkinje cells and DCN neurons were identified by their stereotaxic location and postmortem histology. Purkinje cell identity was further confirmed by the presence of complex spikes. Signals were bandpass filtered (200 $\mathrm{Hz}-20 \mathrm{kHz})$, amplified $(2000 \times)$ and digitized $(20 \mathrm{kHz})$ using a PCIMIO16XE data acquisition card (National Instruments) and custom Labview software. Waveforms were sorted offline using principal component analysis using Plexon.

Chronic infusion of the cerebellum. For the purposes of this paper, the DYT12 model refers to mice with dystonia induced by infusion of ouabain to the cerebellum as described previously (Calderon et al., 2011). Single cannulas (Plastics One) were stereotaxically implanted at midline in the central region of the cerebellum (anteroposterior, $-6.90 \mathrm{~mm}$ from bregma; dorsoventral, $2 \mathrm{~mm}$ ) and connected to an osmotic pump ( 0.25 $\mu \mathrm{l} / \mathrm{h}$; model 1007D, Alzet). The pump was then placed subcutaneously in the back of the animal. Pumps were filled with solutions of $0.1 \mathrm{~mm}$ ouabain made in water and $0.01 \%$ methylene blue $(\mathrm{w} / \mathrm{v})$, which enabled postmortem examination of the perfusion site. Ouabain was infused at a rate of $36 \mathrm{ng} / \mathrm{h}$. Infusion of ouabain was terminated at will by sealing the tubing that connected the pump to the cannula. To alleviate pain, immediately after surgery and every $12 \mathrm{~h}$ thereafter, flunixin $(2.5 \mathrm{mg} / \mathrm{kg})$ was administered subcutaneously.

Chronic infusion of ouabain and acute injection of tetrodotoxin. A perfusion cannula with a second auxiliary port was implanted at the coordinates listed above for chronic infusion of the cerebellum. The main port was used to chronically infuse ouabain into the cerebellum. The auxiliary port allowed for acute injection of tetrodotoxin (TTX) into the cerebellum when needed (Calderon et al., 2011). For these injections $5 \mu \mathrm{l}$ of $5 \mu \mathrm{M}$ TTX was injected over 15 min.

Application of ouabain to the surface of the cerebellum. In a single surgery, three large craniotomies $(\sim 1 \mathrm{~mm}$ diameter) were drilled into the posterior fossa and surgical foam sponges were applied to the cerebellar surface. A well was formed surrounding these areas using dental cement. One to two hours after surgery, the behavior of the animal was videotaped (baseline). Thereafter, a solution of $0.1 \mathrm{~mm}$ ouabain or bodipyouabain was applied to the sponges, and animals were videotaped every $30 \mathrm{~min}$ for $2 \mathrm{~h}$. Histology was performed at the end of the experiment.
Dystonia scale. The presence of dystonia and its severity were quantified using a previously published scale (Calderon et al., 2011) briefly as follows: 0 , normal behavior; 1 , abnormal motor behavior, no dystonic postures; 2 , mild motor impairment, dystonic-like postures when disturbed; 3, moderate impairment, frequent spontaneous dystonic postures; 4 , severe impairment, sustained dystonic postures. Assessment of locomotor disability was made independently by four colleagues (none of the authors). Scorers were first trained by viewing the same set of training videos of mice with movement disorders. Scorers were then asked to identify specific movement abnormalities and were then informed of the score the behavior should receive. These same four scorers then received video clips of individual mice for which they provided scores. All scorers saw the same video clips and were blind to the procedures performed on the animals. Their scores were decoded and averaged by the authors.

Accelerating rotarod. A Rotamex-5 (Columbus Instruments) with a 3 $\mathrm{cm}$ diameter rod elevated $55 \mathrm{~cm}$ was accelerated at a rate of $0.1 \mathrm{~cm} / \mathrm{s}$. The latency to fall was automatically recorded using infrared photocells. Each animal was tested on a daily basis with 10 trials per session. A resting intertrial interval of $2 \mathrm{~min}$ was given to each animal. Mice were trained for $7 \mathrm{~d}$ before the experiment to enable them to reach maximum proficiency.

Analysis of apoptotic cell death. The cerebellum was perfused with vehicle or $36 \mathrm{ng} / \mathrm{h}$ ouabain for $20 \mathrm{~h}$. Animals were then decapitated and brains were cryosectioned $(10-20 \mu \mathrm{m})$. Terminal deoxynucleotidyl transferase dUTP nick end labeling (TUNEL) was used to identify dead apoptotic cells and sections were then costained with Hoechst to label nuclei. For regions of interest, the number of TUNEL-positive and Hoechstpositive cells were counted and the ratio of dead/total cells determined.

Statistics. The coefficient of variation (CV) of interspike intervals (ISIs) is defined as the standard deviation (SD) of the ISIs divided by the mean and can serve as a measure of firing irregularity [CV ISI $=(S D$ ISI)/(mean ISI)]. Normalized ISI histograms for each cell were generated using a bin size of $500 \mu \mathrm{s}$. For most experiments, an unpaired Student's $t$ test was used to assess significance. For behavioral experiments with paired experiment conditions, a Wilcoxon matched-pairs signed-ranks test was used. Differences were considered significant if $p<0.05$.

\section{Results \\ DCN neurons in DYT12 dystonic mice exhibit high-frequency burst firing}

The DCN contains the majority of projection neurons leaving the cerebellum. For a change in cerebellar activity to result in dystonia, as suggested by the DYT12 model of Calderon et al. (2011), the output of the cerebellum must be altered. It is therefore expected that the abnormal cerebellar EEG activity in dystonic DYT12 mice would be reflected as a change in DCN activity. To explore this possibility, recordings from DCN cells in awake head-restrained dystonic mice and control mice (Fig. 1A) were performed. Compared with control DCN neurons (Fig. 1A), cells from dystonic mice displayed abnormal high-frequency burst firing. Although the average firing rate was not different between the two groups (Fig. $1 B$; dystonic mice, $49.1 \pm 6.8$ spikes/second $(\mathrm{sp} / \mathrm{s})$; controls, $43.9 \pm 6.7 \mathrm{sp} / \mathrm{s} ; p=0.58)$, the predominant firing rate of DCN neurons from dystonic mice exhibited a $>2$ fold increase (Fig. 1C; predominant firing rate: dystonic mice, $138.6 \pm 20.9 \mathrm{sp} / \mathrm{s}$; control mice, $52.1 \pm 5.5 \mathrm{sp} / \mathrm{s} ; p=0.0001)$. The change in predominant firing rate in the absence of a change in average firing rate confirms that in dystonic mice DCN activity is converted from normal tonic activity to firing characterized by periods of high-frequency bursting punctuated by relative quiescence. To further quantify changes in DCN firing, the CV of ISIs was calculated. DCN neurons in dystonic mice on average had a significantly higher $\mathrm{CV}$ than those in control animals (Fig. $1 D$; CV: dystonic mice, $1.16 \pm 0.07$; control mice, $0.72 \pm 0.07 ; p=$ $0.0007)$. Since the average firing rate was not different between 
A
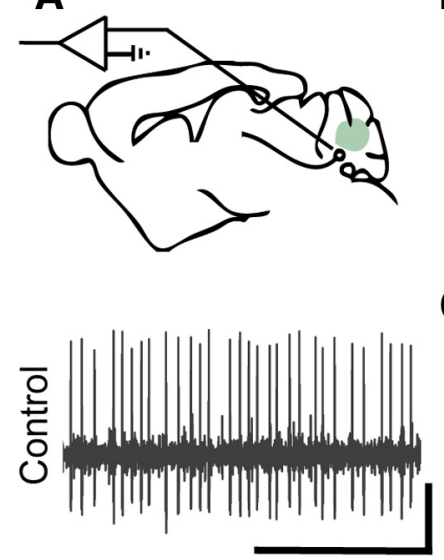

B

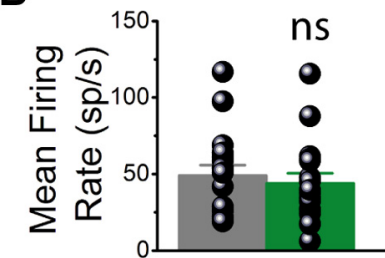

C
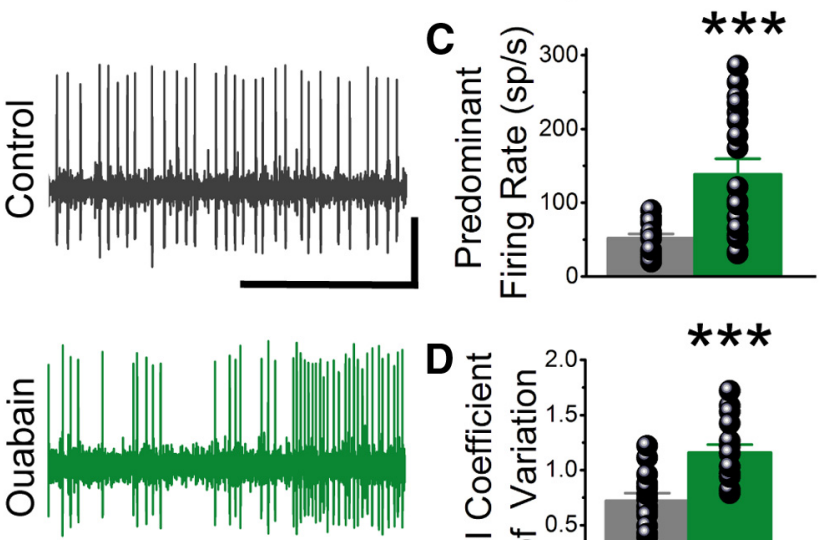

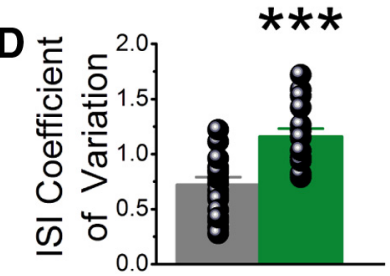

Figure 1. Neurons in the DCN exhibit high-frequency bursting activity in awake dystonic mice with cerebellar infusion of ouabain. $A$, Schematic, DCN neurons were recorded in vivo from awake head-restrained mice with either saline or ouabain infusion to the cerebellum. We compared recordings from animals with infusion of ouabain $(N=6)$ to those with infusion of saline $(N=4)$. Irregular burst firing of DCN neurons recorded from dystonic animals was identifiable in raw traces (green) compared with those of saline-infused controls (gray). Scale bar: 500 ms by $100 \mu \mathrm{V}$. B, Average firing rate defined as number of spikes/recorded time did not differ between control and dystonic animals. n.s., Not significant. $p>0.05$, mean \pm SEM. C, DCN neurons from dystonic (green) mice exhibit an increased predominant firing rate (1/ISI histogram mode) compared with animals with infusion of saline (gray), indicating that when these neurons fire, they do so most commonly in high-frequency bursts $\left({ }^{* *} p<0.001\right.$, mean \pm SEM). $\boldsymbol{D}, \mathrm{DCN}$ neurons recorded in dystonic animals (green) exhibit a higher ISI CV than those from controls (gray). ${ }^{* *} p<0.001$, mean $\pm S E M, n=17,17$.

the two groups, the increase in the CV in cells from dystonic mice solely reflects an increase in the SD of the ISIs. These results demonstrate that the abnormal cerebellar EEG activity (Calderon et al., 2011) in this DYT12 model is reflected in the output of the cerebellum as high-frequency $(>100 \mathrm{~Hz})$ burst firing of DCN neurons.

\section{Silencing the cerebellum alleviates dystonia in the DYT12 model}

If erratic high-frequency burst firing of DCN neurons underlies dystonia, it would be expected that aborting this activity would alleviate dystonic symptoms. This proposition is corroborated by reports that removal of the cerebellum or silencing of cerebellar activity results in ataxia but not dystonia (Dow and Moruzzi, 1958; LeDoux et al., 1993). Therefore, if abnormal bursting of cerebellar neurons underlies dystonia, then acute silencing of the cerebellum should convert dystonic symptoms to ataxic ones. To silence the cerebellum, action potential generation was blocked by injecting the voltage-gated sodium channel blocker TTX into the cerebellum of dystonic mice. Within 15-30 min of TTX injection, dystonia was reduced substantially (Fig. 2). To quantify this change, animals were assessed on a previously described dystonia scale (Calderon et al., 2011) before application of TTX and $30 \mathrm{~min}$ after (Fig. 2B). The average dystonia score decreased from $3.4 \pm 0.6$ in dystonic animals before TTX to $1.2 \pm 0.430$ min after TTX administration $(N=6, p=0.031)$. Since on this
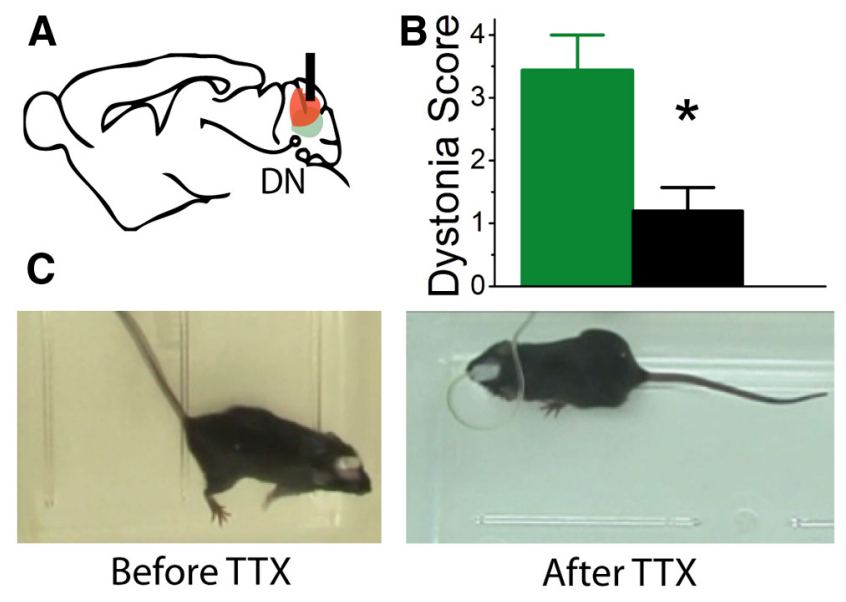

Figure 2. Silencing the cerebellum using TTX acutely alleviates dystonia. $\boldsymbol{A}$, In dystonic mice with infusion of ouabain to the cerebellum, TTX was applied to silence the cerebellum $(N=6)$. $\boldsymbol{B}, \boldsymbol{C}$, As early as $15 \mathrm{~min}$ after TTX infusion, dystonic symptoms began abating and dystonia was largely alleviated by $\sim 30$ min post-TTX infusion (green, pre-TTX; black, 30 min post-TTX). ${ }^{*} p<$ 0.05 , mean \pm SEM.

scale a score $<2$ represents absence of dystonia, this finding supports the hypothesis that erratic high-frequency burst firing of cerebellar output underlies dystonia.

\section{Purkinje cells in dystonic mice exhibit abnormal high- frequency bursting activity}

DCN neurons receive excitatory glutamatergic input from mossy fibers and climbing fibers which originate outside of the cerebellum. They also receive axonal projections from Purkinje cells, that provide GABAergic input. Multiple Purkinje cells converge onto a single DCN neuron (Ito et al., 1964) and Purkinje cells can directly modulate DCN activity via strong inhibitory synapses (Mouginot and Gähwiler, 1995; Gauck and Jaeger, 2000, 2003). Since infusion of ouabain was limited to the cerebellum, the abnormal DCN activity identified could be driven by dysfunctional Purkinje cells. To address this possibility, recordings from Purkinje cells were performed in awake head-restrained mice with and without dystonia (Fig. $3 A ; N=7$ dystonic animals, 4 control animals).

Purkinje cells recorded from control animals fired tonically, demonstrating activity characteristic of this neuronal type (Brookhart et al., 1950; Fig. 3A). However, Purkinje cells from dystonic animals exhibited erratic burst-firing (Fig. $3 A$ ). This firing pattern was qualitatively similar to the activity of DCN neurons recorded from dystonic animals. The average firing rate, predominant firing rate, and CV of Purkinje cells from control animals were compared with those from dystonic mice. There was no significant difference in the average firing rate of Purkinje cells from dystonic and nondystonic animals (dystonic mice: $59.9 \pm 8.6 \mathrm{sp} / \mathrm{s}, n=19$; controls: $55.2 \pm 4.7 \mathrm{sp} / \mathrm{s}, n=14 ; p=0.79$; Fig. $3 B$ ). However, both the predominant firing rate (Fig. $3 C$; dystonic mice, $155.2 \pm 19 \mathrm{sp} / \mathrm{s}$; controls, $65.1 \pm 8 \mathrm{sp} / \mathrm{s} ; p=$ 0.0004 ) and CV (Fig. 3E; dystonic mice, $1.10 \pm 0.09$; controls, $0.50 \pm 0.03 ; p=0.00001)$ of Purkinje cells recorded in dystonic mice were increased by $>2$-fold compared with controls. Indeed, ISI histograms of Purkinje cells from dystonic animals consistently exhibited a left-shifted peak compared with those from saline-infused controls (Fig. 3C). These observations confirm that in vivo Purkinje cells in the DYT12 model fire primarily in high-frequency bursts similar to DCN neurons. This finding is consistent with the hypothesis that abnormal Purkinje cell out- 

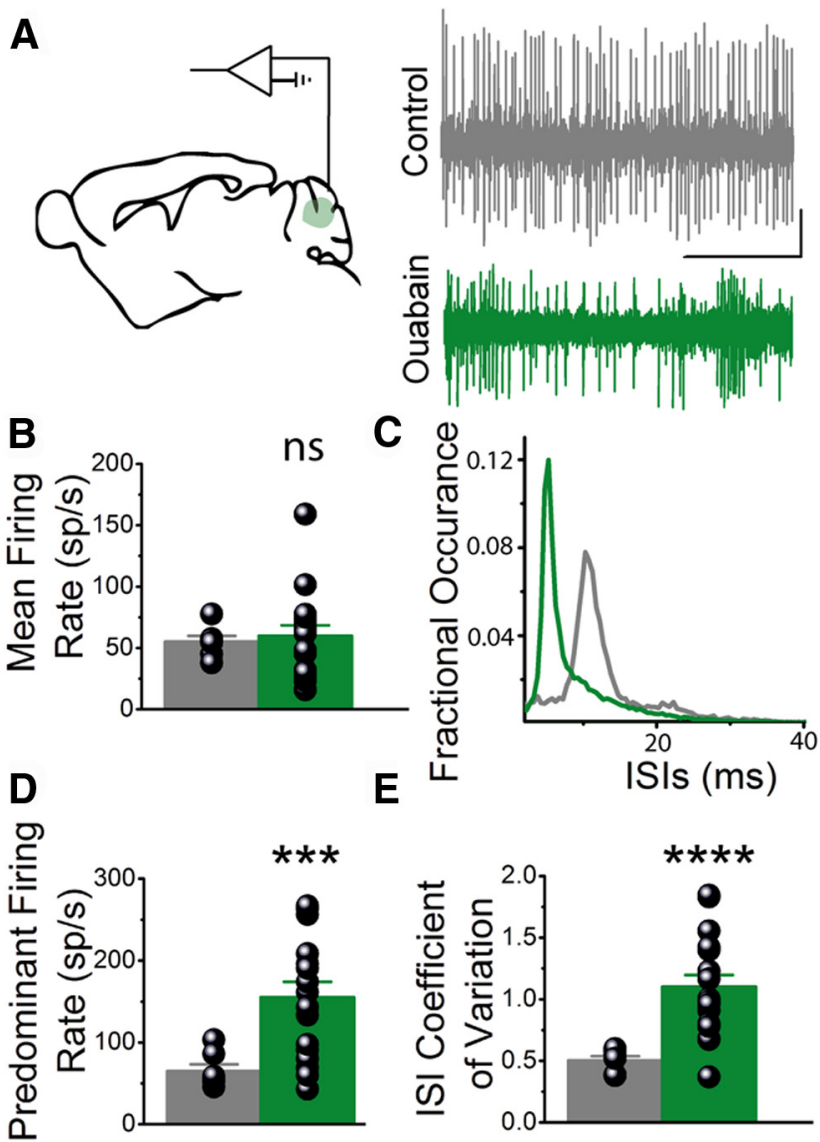

Figure 3. The activity of Purkinje cells in awake dystonic mice is transformed to highfrequency burst firing. $\boldsymbol{A}$, In vivo recordings of Purkinje cells (schematic) were performed in awake head-restrained animals with infusion of saline to the cerebellum (gray) and in animals with dystonia due to infusion of ouabain (green). Raw traces of the activity of Purkinje cells from control animals exhibited normal tonic firing characteristic of this cell type (control, gray) while traces from Purkinje cells in dystonic animals displayed abnormal burst firing (ouabain, green). Scale bar for both traces, $250 \mathrm{~ms}$ by $100 \mu$ V. B, Similar to DCN neurons recorded in vivo, Purkinje cells from dystonic animals do not exhibit a change in average firing rate. n.s., Not significant, $p>0.05$, mean \pm SEM. C, Representative ISI histograms of Purkinje cells from an animal with infusion of saline (gray) and a dystonic animal with infusion of ouabain (green). Compared with the histogram from the control cell, the histogram of the Purkinje cell from the dystonic animal is shifted to the left. This shows that the Purkinje cell from the dystonic animal exhibits high-frequency activity characterized by short ISIs (the leftward-shifted peak). D, E, Purkinje cells recorded from dystonic mice exhibit an increase in predominant firing rate $\left(\boldsymbol{D}^{* * *} p<0.001\right)$ and an increase in $|S|$ CV $\left(E_{*}^{* * * *} p<0.0001\right)$ compared with controls mean \pm SEM; $n=4,7$ animals, $n=13,19$.

put, at least in part, contributes to DCN firing changes and dystonia in the DYT12 model.

Partial block of sodium pumps in the cerebellar cortex alone is sufficient to induce dystonia

The previous sections demonstrate that in dystonic mice both Purkinje cells and DCN neurons exhibit similar irregularities in firing. This suggests that the abnormal activity in DCN neurons may be driven by abnormal Purkinje cell activity. It is plausible then that application of ouabain to the cerebellar cortex alone might be sufficient to induce dystonia. To test this hypothesis, ouabain was topically applied to the cerebellar cortex of wild-type mice by drilling three large craniotomies and then acutely applying surgical foam soaked with ouabain $(0.1 \mathrm{mM})$ to the cerebellar surface exposed by the craniotomies (Fig. 4A,B). Application of ouabain to the cerebellar surface initially resulted in ataxia, which was then followed by dystonia (average time of onset of dystonia:
$37 \pm 14 \mathrm{~min}, N=7)$. Dystonia was reflected quantitatively as an increase in the dystonia score of these animals (average score: $0.2 \pm 0.1$ before ouabain and $3.3 \pm 0.21 \mathrm{~h}$ after applying ouabain; Fig. $4 B ; p=0.016$ ). Because diffusion in the brain is slow (Syková and Nicholson, 2008) and the onset of dystonia in these mice is relatively fast, it is likely that ouabain did not diffuse to the DCN in these animals. To test this, in a subset of experiments $(N=3)$ a fluorescently tagged analog of ouabain (bodipy-ouabain) was applied to the cerebellar cortex and mice were killed $1 \mathrm{~h}$ later, at which point all were exhibiting dystonia. The cerebella of these mice were bisected to quantitatively determine the diffusion of ouabain using fluorescence microscopy (Fig. $4 A, B, D$ ). The average half-width of diffusion for bodipy-ouabain in dystonic animals was $0.62 \pm 0.07 \mathrm{~mm}$ whereas the DCN begin $\sim 2.3 \mathrm{~mm}$ below the cerebellar surface (Franklin and Paxinos, 2008). These experiments suggest that partially blocking sodium pumps in the cerebellar cortex is sufficient to cause dystonia and that exposure of DCN to ouabain is not required to induce symptoms.

\section{Cerebellar Purkinje cells are sensitive to partial block of sodium pumps}

The fact that partial block of sodium pumps in the cerebellar cortex alone results in dystonia suggests that dystonia in DYT12 is at least partially driven by aberrant Purkinje cell output. Purkinje cells are spontaneously active neurons that are intrinsically active at a constant pace with an average firing rate of $\sim 50 \mathrm{~Hz}$ (Latham and Paul, 1971; Hounsgaard, 1979; Häusser and Clark, 1997; Raman and Bean, 1997). Purkinje cells also have a particularly high sodium channel density and brief spike duration, which causes the influx of large amounts of sodium per action potential (Llinás and Sugimori, 1980; Raman and Bean, 1997; Carter and Bean, 2009). Because of these characteristics, it is expected that Purkinje cells would have a high reliance on the sodium pump to help maintain normal ionic concentrations during spontaneous activity. Therefore, it is expected that the intrinsic activity of Purkinje cells will be altered by partial block of sodium pumps.

To address this possibility, ouabain was applied to Purkinje cells recorded in vitro from cerebellar slices in which GABAergic and glutamatergic synaptic transmission was pharmacologically blocked (Fig. 5A). Whereas under control conditions the spontaneous activity of Purkinje cells is regular (Fig. $5 A$ ), applying $10 \mathrm{nM}$ ouabain, a concentration $\approx 5 \times$ lower than its $K_{\mathrm{D}}$ for sodium pumps in rodents (Sweadner, 1989), increased the firing rate of these cells and ultimately caused a conversion from tonic firing to high-frequency bursting activity (Fig. $5 B, C ; N=6, n=6$ ). Purkinje cells were capable of bursting continuously for extended periods of time. In the presence of ouabain, the CV of Purkinje cells increased from an average of $0.09 \pm 0.01$ before ouabain to $0.93 \pm 0.58$ after $1 \mathrm{~h}$ of ouabain perfusion and $1.65 \pm 0.54$ after $2 \mathrm{~h}$ (Fig. 5D; $p=0.034$ ), suggesting that Purkinje cell activity is highly sensitive to dysfunction of sodium pumps.

Despite the fact that DCN neurons are also intrinsically active and fire spontaneously at rates approximately comparable to Purkinje cells (Jahnsen, 1986; Llinás and Mühlethaler, 1988), they have a lower sodium channel density and have broader action potentials than Purkinje cells (Raman et al., 2000). Therefore, it might be expected that these neurons would be less sensitive than Purkinje cells to partial block of sodium pumps. Indeed, bath application of $10 \mathrm{~nm}$ ouabain had little effect on the spontaneous firing of DCN neurons recorded in vitro with synaptic transmission blocked $(N=5, N=5$; Fig. $5 F, G)$. There was also little effect on the $\mathrm{CV}$ of these neurons (before ouabain, $0.07 \pm 0.02$; after $1 \mathrm{~h}$ of ouabain perfusion, $0.08 \pm 0.02$; after $2 \mathrm{~h}$, 

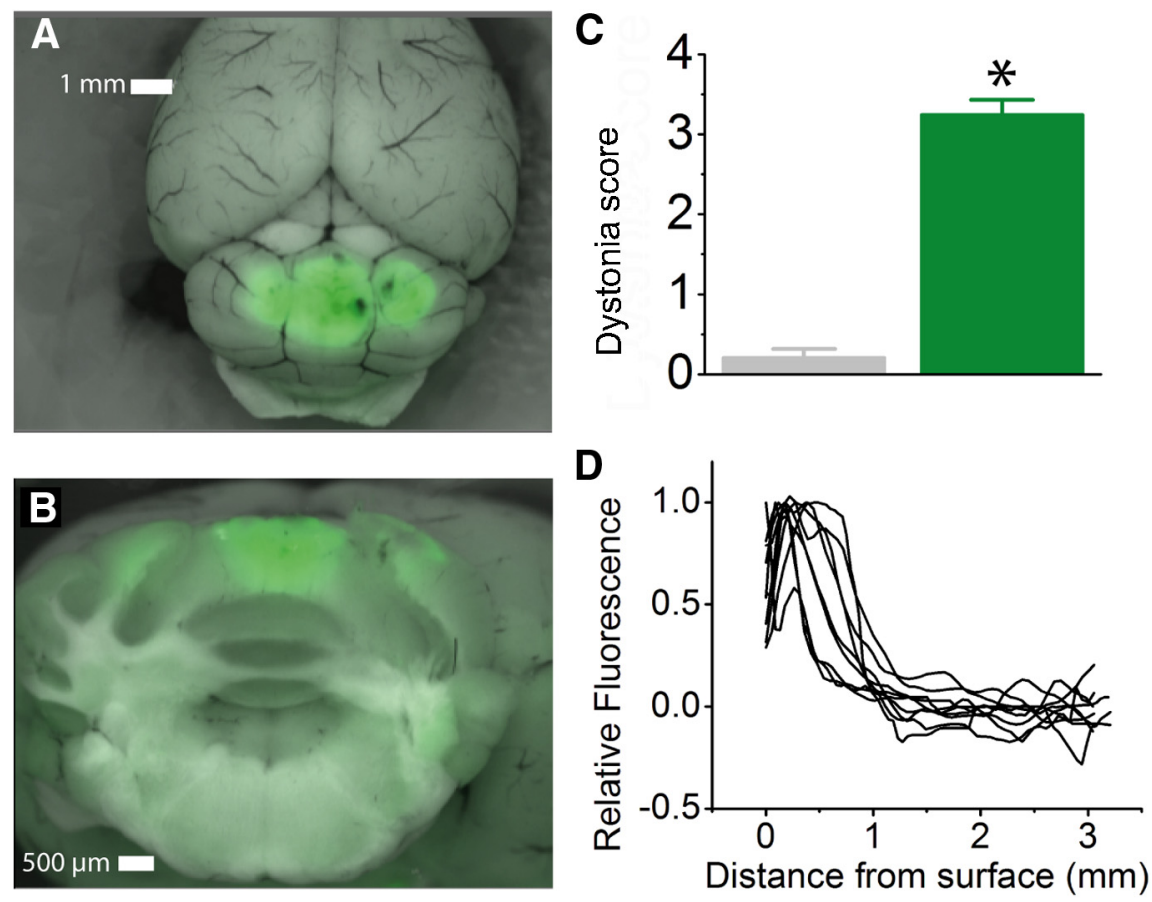

Figure 4. Ouabain application to the cerebellar cortex is sufficient to induce dystonia. $\boldsymbol{A}$, Photograph of the brain surface after bodipy-ouabain application to the cerebellar cortex via sponges placed over three craniotomies. $\boldsymbol{B}$, Coronal section through the cerebellum demonstrating that bodipy-ouabain diffusion is limited to the cerebellar cortex. C, Quantification of the dystonia score before (gray) and $1 \mathrm{~h}$ after (green) ouabain application to the cerebellar cortex ( $N=7,{ }^{*} p<0.05, p=0.0156$ Wilcoxon matched-pairs signed-ranks test, mean \pm SEM). $\boldsymbol{D}$, Graph demonstrating the spread of bodipy-ouabain at nine sites from three mice.

$0.06 \pm 0.01$; Fig. $5 G)$. These findings suggest that the abnormal burst firing of DCN cells in DYT12 mice is likely driven largely by abnormal aberrant Purkinje cell activity.

\section{Ouabain-induced cerebellar dystonia is reversible}

As reported earlier, when sodium pumps are partially blocked Purkinje cells can burst in excess of $2 \mathrm{~h}$ without dying. In fact, we found that in vitro the effects of ouabain on Purkinje cell activity were reversible such that, following washout of ouabain, Purkinje cell activity reverted from high-frequency bursting to regular tonic firing (Fig. $6 A, B ; n=6$ ).

Since the abnormal Purkinje cell activity caused by ouabain is reversible and this aberrant activity may cause dystonia in the DYT12 mouse model, it is plausible that terminating infusion of ouabain in vivo would alleviate dystonia. EMG recordings from animals $(N=3)$ in which cerebellar ouabain perfusion was terminated revealed that dystonia abated within a few days after halting perfusion of ouabain. The prolonged cocontractions of agonist-antagonist muscle pairs seen in the dystonic mice while ouabain was being perfused diminished $24 \mathrm{~h}$ after infusion of ouabain was terminated and by the fifth day post-termination muscle activity appeared normal (Fig. 6C). The dystonia scores of all animals examined decreased after termination of ouabain perfusion $(N=11$ mice; average dystonia of $3.3 \pm 0.2$ diminished to $0.8 \pm 0.2$ on the fifth day after the termination of perfusion; Fig. $6 D)$. Performance of the mice on an accelerating rotarod was used to quantitatively assess abnormalities in cerebellar function that may persist after termination of infusion of ouabain $(N=10$ ouabain animals, 4 saline controls). Dystonia caused by ouabain infusion to the cerebellum was accompanied by a decrease in the latency to fall in all mice examined (average latency of fall: before ouabain infusion, $64.56 \pm 0.63 \mathrm{~s}$; during ouabain infusion,
$1.06 \pm 0.56 \mathrm{~s})$. After stopping infusion of ouabain, the performance of each mouse on the rotarod improved on a timescale comparable to, but somewhat trailing, that with which dystonia abated (average latency of fall: $5 \mathrm{~d}$ after infusion, $13.94 \pm$ $0.66 \mathrm{~s} ; 10 \mathrm{~d}$ after infusion, $40.89 \pm 0.42 \mathrm{~s}$; Fig. 6D). It is notable that in some mice, symptoms alleviated as early as $2 \mathrm{~d}$ after the termination of infusion of ouabain and rotarod performance recovered completely to baseline values in a comparable length of time (Fig. $6 G, H$ ). This suggests that most, if not all, of the motor deficits in this DYT12 model can be completely alleviated by stopping infusion of ouabain.

Calderon et al. (2011) found that acute infusion of ouabain to the cerebellum induces dystonia. Further, applying ouabain to the cerebellar cortex also resulted in dystonia within $40 \mathrm{~min}$. Combined with the reversibility studies shown here, these findings suggest that changes in cerebellar activity rather than cerebellar pathology may underlie dystonia in this DYT12 model.

\section{There is little cell death in DYT12 mice exhibiting dystonia}

Data from the previous section suggest that acute changes in cerebellar activity caused by ouabain are sufficient to cause dystonia. Since mice recovered to near-normal behavior after termination of ouabain infusion, it is likely that there is little cell death in the cerebellum.

TUNEL assay was performed on sections made from dystonic animals to determine the extent of cell death in the cerebellum caused by infusion of ouabain. By comparing Hoechst staining and TUNEL-positive cells, the percentage of cell death in six different areas relative to the site of ouabain infusion was determined (Fig. 7). The percentage of cell death in dystonic mice was compared with that seen in mice with saline infusion to the cerebellum. At the site of the cannula, there was cell death in animals with infusion of saline and in animals with infusion of ouabain (Fig. $7 B$ ). At sites beneath the cannula, mice with ouabain infusion had $\sim 10 \%$ cell death whereas cell death in control animals at this site was minimal (Fig. $7 B$ ). Even though apoptosis in dystonic mice close to the site of ouabain infusion exceeds that measured in controls (Fig. $7 B, D ; p=0.018$ for $b ; p=0.009$ for $d$ ), the percentage of death in even the most affected regions was $<20 \%$. This suggests that cell death is not the primary cause of symptoms in ouabain-infused mice.

\section{Discussion}

The purpose of this study was to determine the neuronal substrates of dystonia in a rodent model of DYT12 dystonia. We find that in dystonic mice, DCN neurons exhibit abnormal highfrequency burst firing. Purkinje cells exhibited similar firing abnormalities and were found to be exquisitely sensitive to partial block of sodium pumps. These findings implicate abnormal Purkinje cell high-frequency burst firing and subsequent abnormal cerebellar output as the instigator of dystonia in this model of DYT12. 

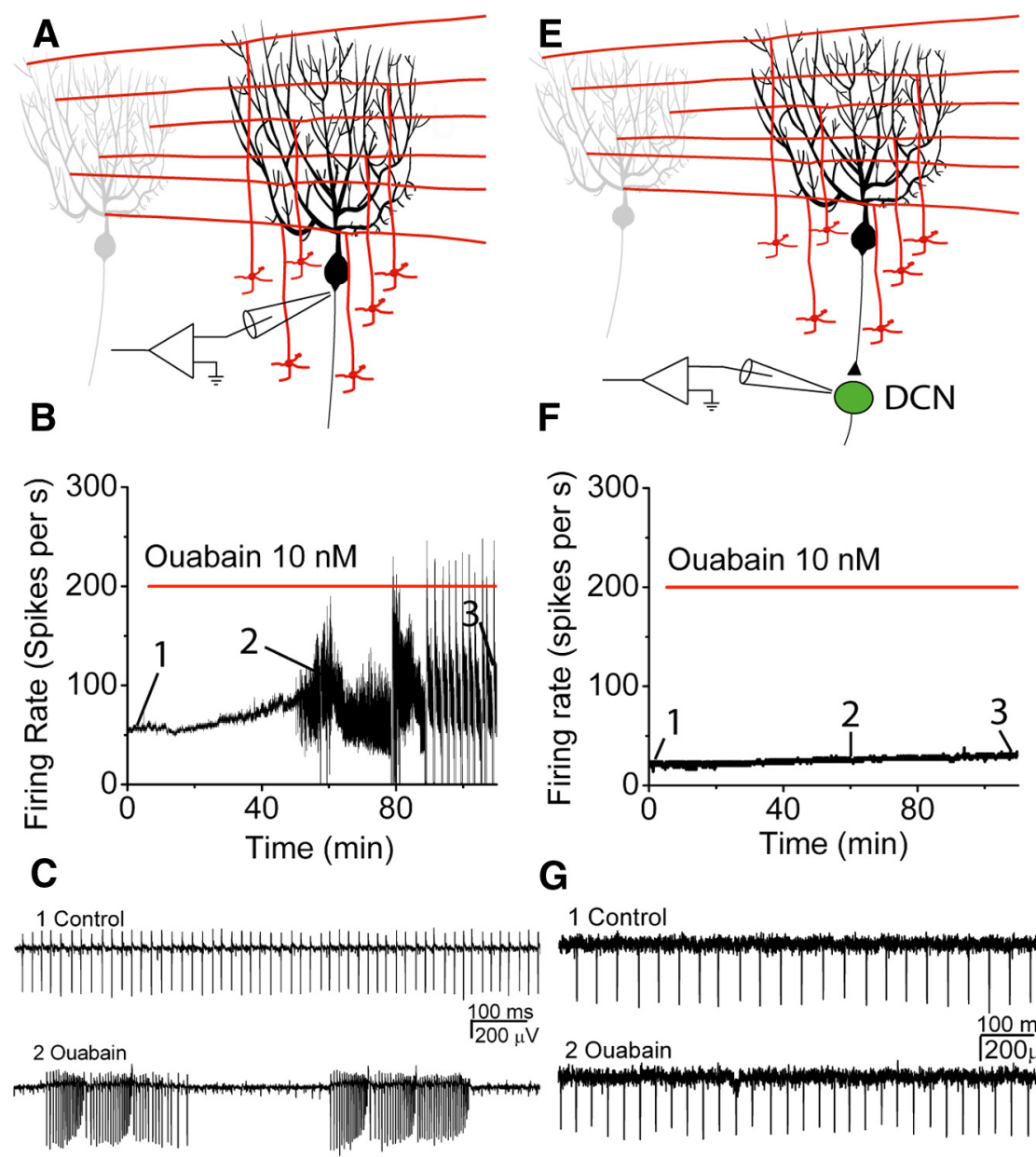

G 1 Control
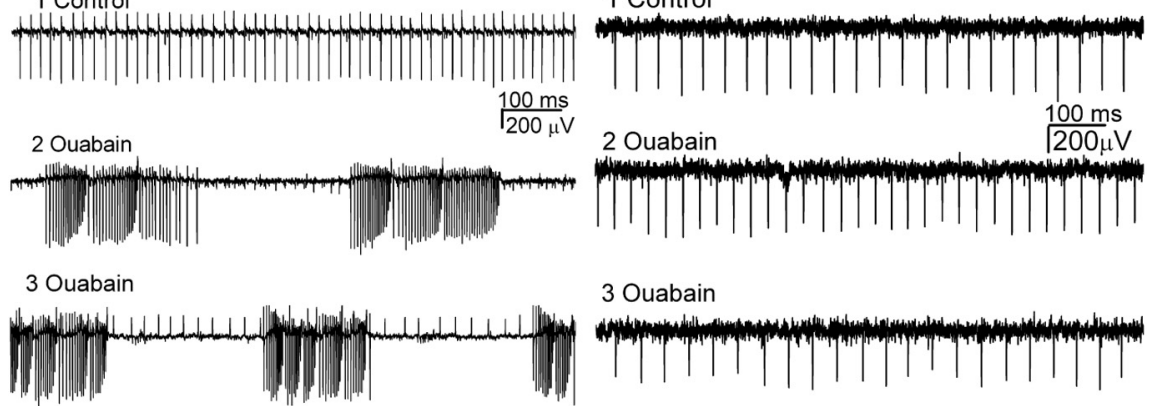

3 Ouabain

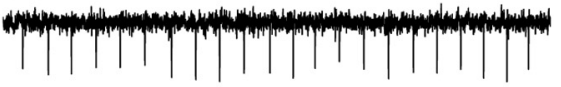

D

H
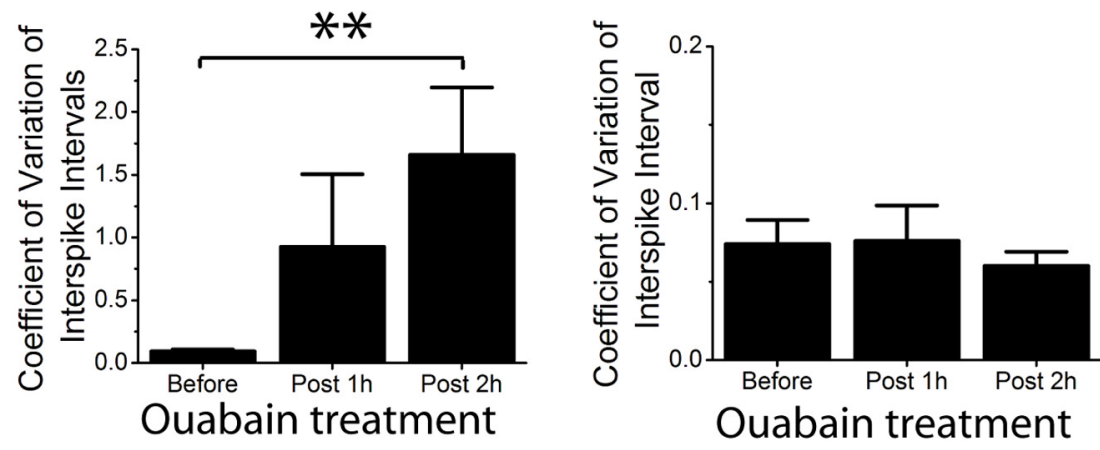

Figure 5. Purkinje cells are highly sensitive to partially blocking sodium pumps. $\boldsymbol{A}, \boldsymbol{B}$, The firing rate of a representative Purkinje cell increases after the application of $10 \mathrm{~nm}$ ouabain, ultimately resulting in burst firing. The red line indicates the start of ouabain perfusion. $\boldsymbol{C}$, Raw traces from the same cell as in $\boldsymbol{A}$ and $\boldsymbol{B}$, demonstrating the firing pattern before ouabain and 1 and $2 \mathrm{~h}$ after ouabain administration. $\boldsymbol{D}$, The CV of ISIs of Purkinje cells before ouabain perfusion and then at 1 and $2 \mathrm{~h}$ after the initiation of ouabain perfusion $\left(n=5,{ }^{* *} p<0.01\right.$, mean \pm SEM). $\boldsymbol{E}, \boldsymbol{F}$, The firing rate of a representative neuron in the $D C N$ does not change after application of $10 \mathrm{~nm}$ ouabain. $G$, Raw traces from the same cell demonstrate the firing of the DCN neuron before and 1 or $2 \mathrm{~h}$ after ouabain perfusion. $\boldsymbol{H}$, The CV of ISIs of DCN neurons before and 1 or $2 \mathrm{~h}$ after perfusion of ouabain. There was no significant difference found in firing at these different times $(n=6, p>0.05$, mean \pm SEM).

Dystonia has traditionally been considered to be a basal ganglia disorder (Albin et al., 1989) based on observations in which damage in the basal ganglia of humans, primates, and rodents results in dystonia (Bhatia and Marsden, 1994; Guehl et al., 2009;
Schneider and Bhatia, 2010; Baron et al., 2011). Moreover, deep brain stimulation of basal ganglia alleviates symptoms in many dystonic patients (Vidailhet et al., 2005). However, only a minority of inherited dystonias are associated with overt pathological abnormalities (Breakefield et al., 2008; Holton et al., 2008; Bragg et al., 2011; Standaert, 2011; Paudel et al., 2012; Goto et al., 2013). A recent study examined brains of DYT12 patients and compared them with the brain of a nonaffected carrier sibling. This study found marked neuronal loss and gliosis throughout multiple nuclei of the basal ganglia, the brainstem, and the cerebellum of patients, implicating these areas as potential brain sites associated with DYT12 (Oblak et al., 2014).

In recent years, physiological evidence that suggests that the basal ganglia are not the only brain areas involved in dystonia has also been accumulating. In fact, abnormal activity in the cerebellum has been demonstrated in a number of inherited dystonias, suggesting that the cerebellum may be involved in this disorder (Carbon et al., 2004, 2013; Asanuma et al., 2005; Jinnah and Hess, 2006; Argyelan et al., 2009; Berti et al., 2011; Sadnicka et al., 2012; Blood, 2013). Further, neurosurgical studies primarily performed in the 1960 s and 1970s demonstrated that lesioning or stimulating the cerebellar dentate nuclei (the most lateral DCN) in some cases alleviates dystonia refractory to other treatments (Zervas et al., 1967; Fraioli and Guidetti, 1975; Cooper, 1976; Davis et al., 1977). Unfortunately, sporadic reports of contradictory results, complications, and unwanted side effects (Gahm et al., 1981; Cooper et al., 1982) led researchers to abandon the cerebellum as a surgical target in favor of the thalamus and the basal ganglia nuclei. Nonetheless, recent studies and approaches have started to re-examine the cerebellum as an appropriate target for treatment of dystonia with an interesting example being the efficacy of transcranial electric stimulation in lessening symptoms in dystonic patients (Koch et al., 2014).

It is noteworthy that some patients with cerebellar disorders present with dystonia (Alarcón et al., 2001; Sethi and Jankovic, 2002; Wu et al., 2004; van Gaalen et al., 2011) and many patients with inherited dystonias have cerebellar abnormalities identifiable through fMRI and PET imaging (Carbon et al., 2004; 2013; Argyelan et al., 2009). In rodents, multiple groups have shown that alterations in cerebellar function can result in dystonia (LeDoux and Lorden, 1998; LeDoux et al., 1998; Pizoli et al., 2002; Raike et al., 2005). A 
A

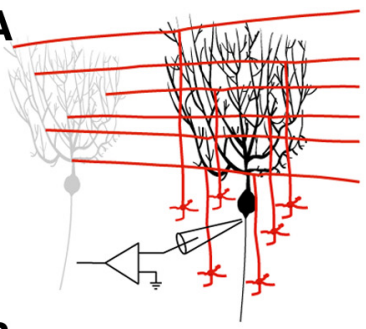

B

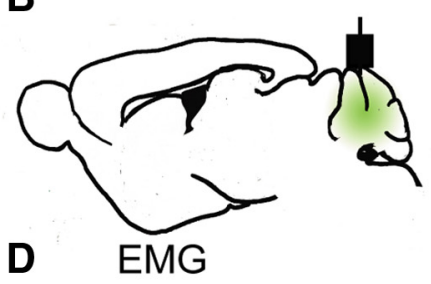

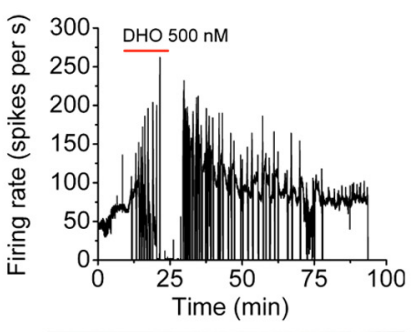

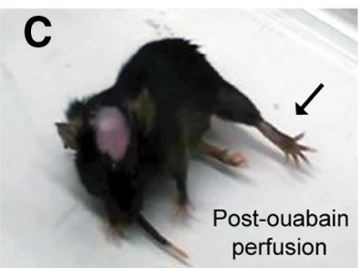

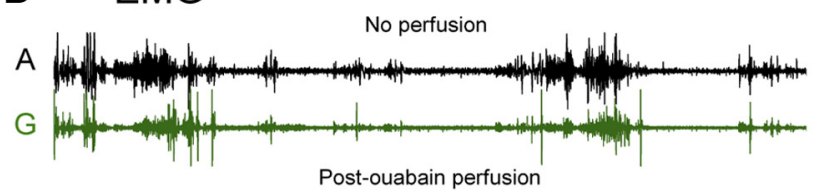
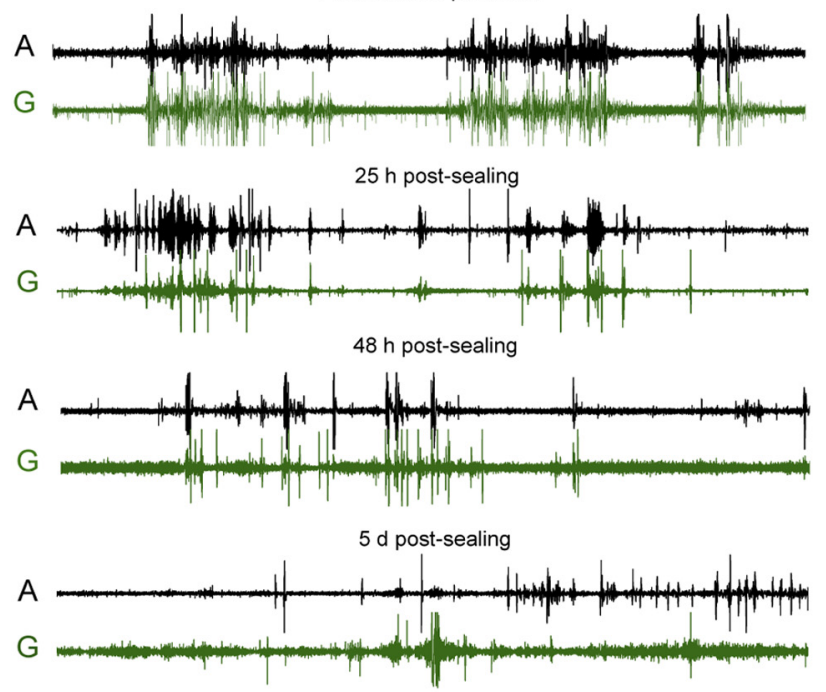

E

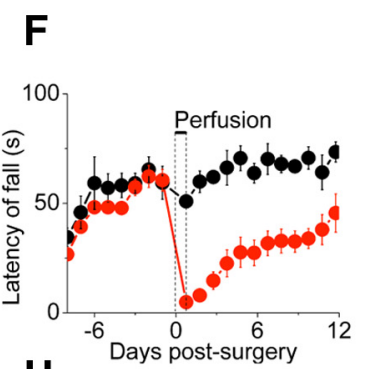

G
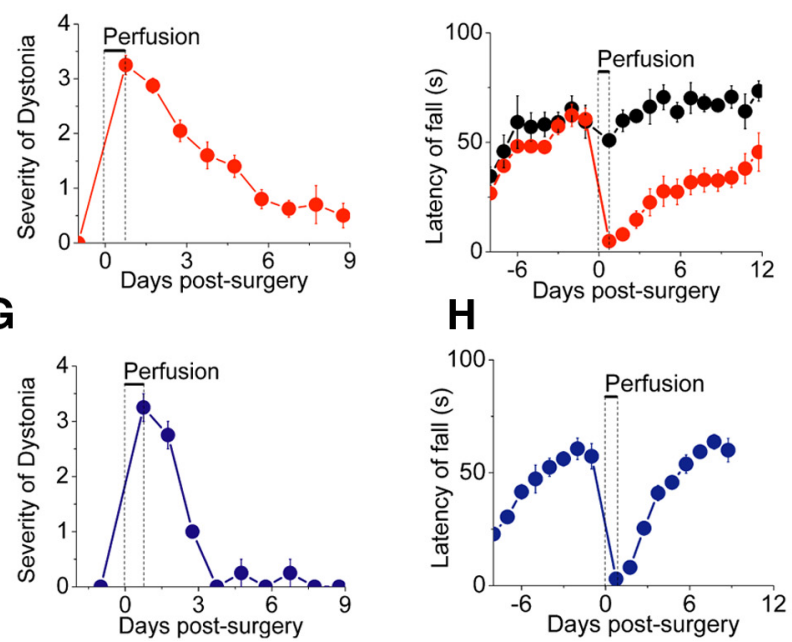

Figure 6. Dystonia caused by infusion of ouabain to the cerebellum is reversible. $\boldsymbol{A}$, Changes in Purkinje cell activity due to perfusion of ouabain in vitro are reversible (schematic). In the example Purkinje cell shown, after application of 500 nm ouabain (red bar) the firing rate increases and then the cell bursts. The firing rate returns to baseline after $50 \mathrm{~min}$ of washout. $\boldsymbol{B}$,

series of elegant papers demonstrated that in the genetically dystonic (dt) rat, abnormal bursting cerebellar output is responsible for dystonia (LeDoux and Lorden, 1998, 2002; LeDoux et al., 1993, 1998), similar to what we find in this model of DYT12. It remains to be established, however, whether abnormal cerebellar activity underlies dystonia in patients.

Recently, novel mutations in ATP1A3 were linked to alternating hemiplegia of childhood (AHC), a disorder characterized by developmental delay and episodes of hemiplegia with dystonic movements (Heinzen et al., 2012; Rosewich et al., 2012). Although the presentation of AHC differs from DYT12, both disorders share symptoms. For example, over half of patients with both disorders suffer from dystonia (Mikati et al., 2000). Interestingly, AHC patients exhibit a baseline ataxia with superimposed attacks of hemiplegia and in some cases dystonia (Sweney et al., 2009). Therefore, similar to DYT12, onset of dystonic symptoms in AHC occurs acutely. It is plausible, then, that our findings may also be relevant to patients with AHC. A recent study has demonstrated that a similar mutation to one found in AHC patients is found in the ATP1A3 mutant mouse Myshkin (Kirshenbaum et al., 2013). These mice also exhibit baseline ataxia. However, similar to most other transgenic mouse models of dystonias, episodic attacks of hemiplegia/dystonia have not been reported, perhaps due to developmental compensation. Our animal model is based on manipulation of sodium pumps in adult mice. Given that AHC occurs developmentally early in life, the relevance of the current findings to AHC remains to be established. It would be of interest to determine the behavioral and electrophysiological phenotype of juvenile mice exposed to ouabain.

Our findings suggest that in DYT12, dystonic symptoms are due to changes in cerebellar activity directly caused by loss of function of sodium pumps. Purkinje cells appear to be highly susceptible to partially blocking sodium pumps. One reason for their exquisite sensitivity to ouabain might be that they only express one isoform of the sodium pump. Sodium pumps containing $\alpha 3$ are expressed in neurons throughout the brain, including Purkinje cells, molecular layer interneurons, granule cells, and DCN neurons of the cerebellum (Brines et al., 1991; Hieber et al., 1991; McGrail et al., 1991; Peng et al., 1997). However, although sodium pumps containing the $\alpha 1$ isoform are expressed ubiquitously throughout the body and also in most neurons, $\alpha 1$ protein is not present in Purkinje cells (Peng et al., 1997).

Another reason for the higher sensitivity of Purkinje cells to ouabain is that the action potential of Purkinje cells is shorter in duration compared with the action potential of cortical or hippocampal pyramidal cells (Bean, 2007). As a consequence of this

\footnotetext{
C, By $18 \mathrm{~h}$ after the initiation of infusion of ouabain to the cerebellum $(\boldsymbol{B})$, mice began exhibiting dystonic postures ( $\boldsymbol{C}$, arrow points to hyperextension of hindlimb often seen in these mice). $\boldsymbol{D}$ EMG signals recorded from anterior tibialis $(A)$ and gastrocnemius $(G)$ muscles in a mouse with infusion of ouabain to the cerebellum. In the first panel, there is alternating activity of this agonist-antagonist muscle pair. The second panel shows cocontraction of both muscles during a dystonic posture after ouabain infusion. The third and fourth panels show a gradual reduction of cocontractions at 24 and $48 \mathrm{~h}$ respectively after infusion of ouabain was terminated. $\boldsymbol{E}_{\text {, }}$ Infusion of ouabain to the cerebellum induces dystonia, which is reversible upon termination of perfusion (period of perfusion demarcated by a black line, $N=11$ ). $\boldsymbol{F}$, Motor performance was assessed using the rotarod for animals with saline (black, $N=4$ ) or ouabain (red, $N=10$ ) perfusion followed by termination. Mice exhibited a precipitous drop in motor performance after the start of infusion of ouabain. Performance returned to normal after perfusion ceased. $\boldsymbol{G}$, $\boldsymbol{H}$, The timescale of recovery in ouabain-infused animals was variable but could occur within $3 \mathrm{~d}$ as shown in an example mouse.
} 

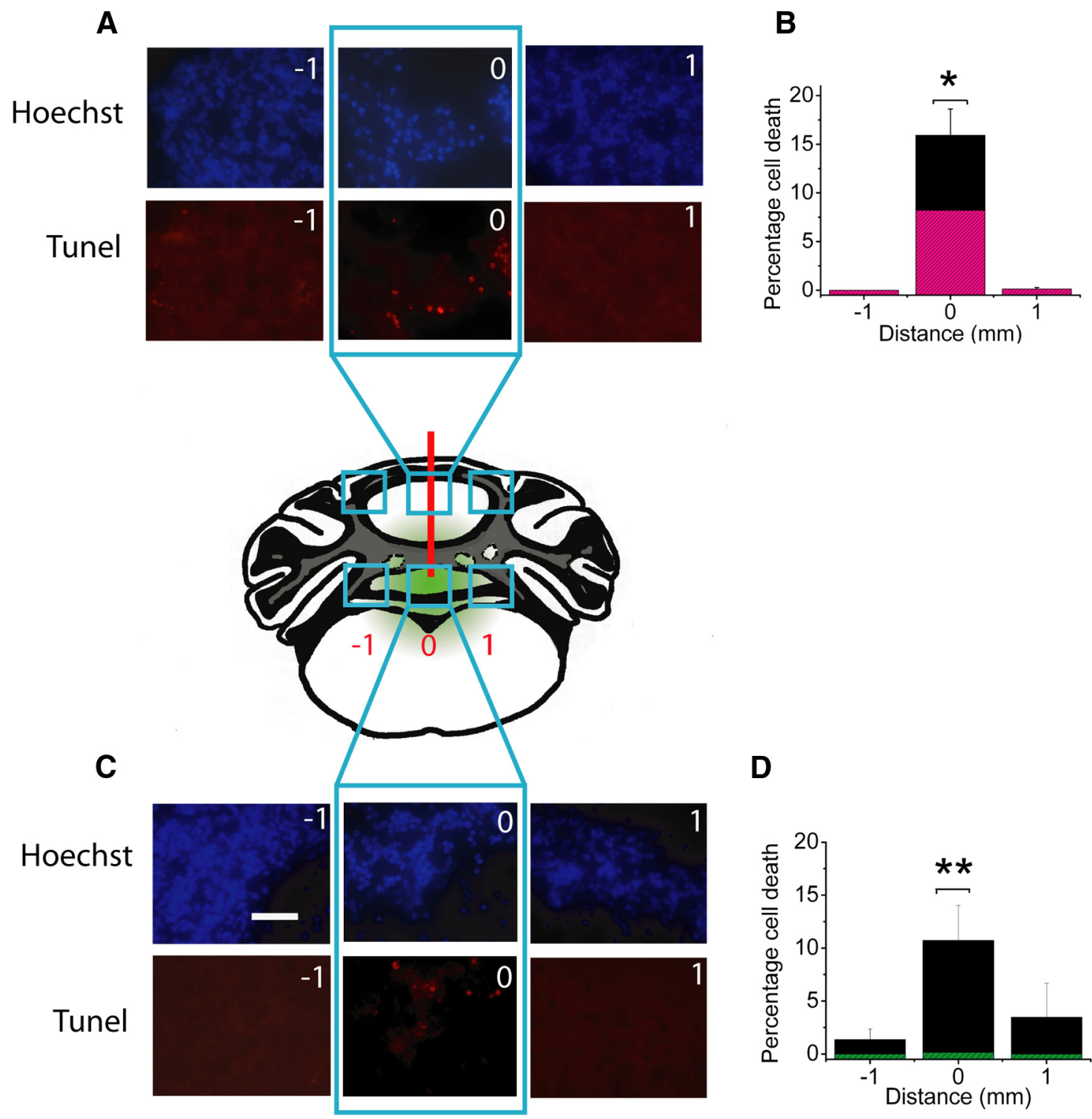

Figure 7. Infusion of ouabain to the cerebellum elicits little cell death in dystonic mice. The schematic shows the region of the cerebellum in which cell death was quantified. Cell death was quantified superficially at the level of cannula implantation and more deeply at the level of ouabain infusion. Zero indicates the site of pump implantation and the distance from this site is indicated in millimeters. $A$, Images of the superficial layers of the cerebellum from a representative mouse with infusion of ouabain to the cerebellum and dystonia. Upper panels show Hoescht staining (blue nuclei) while lower panels show TUNEL-positive cells (red). B, Quantification of the percentage cell death in the superficial layers with either saline (red) or ouabain (black) infusion to the cerebellum (mean \pm SEM). Although both conditions elicited $<20 \%$ cell death, animals with ouabain infusion had significantly more cell death than saline-infused controls ( $\left.{ }^{*} p<0.05\right)$. C, Images of Hoescht (top, blue nuclei) and TUNEL (bottom, red) staining in the layers immediately beneath the cannula implantation site for the same mouse as in $\boldsymbol{A}$. D. Quantification of the percentage cell death in the lower regions for animals with infusion of saline (green) and animals with infusion of ouabain (black, mean \pm $\mathrm{SEM})$. In these regions, animals with infusion of ouabain exhibited significantly more cell death than controls $\left.{ }^{* *} p<0.01\right)$. However, cell death even in ouabain-infused animal did not exceed $\sim 15 \%$. Scale bar, $40 \mu \mathrm{m} . N=3$ animals in each condition.

brief action potential, sodium channel inactivation in Purkinje cells during the downstroke is incomplete and recovery begins sooner and from more hyperpolarized voltages (Carter and Bean, 2009). Additionally, Purkinje cells have an extremely high sodium channel density such that only partial recovery from inactivation is necessary before the next spike can be generated (Carter and Bean, 2011). Although these properties allow Purkinje cells to fire repeatedly at high frequencies and likely underlie the ability of Purkinje cells to generate complex spikes (Raman and Bean, 1997), they come at a high metabolic cost (Carter and Bean, 2009). With each action potential, Purkinje cells let in twice as many sodium ions as are needed to generate an action potential (Carter and Bean, 2009). This coupled with the high firing rates exhibited by these cells results in a large sodium load that must be handled by the sodium pump. The sodium pump is capable of scaling its activity depending on the intracellular sodium concentration (Nakao and Gadsby, 1989). This characteristic of sodium pumps could also potentially make them a versatile tool for controlling the membrane potential of the cell and its excitability. Indeed, it was recently demonstrated that the sodium pump contributes to the afterhyperpolarization and therefore the excitability of pyramidal hippocampal neurons (Gulledge et al., 2013). Our studies show that Purkinje cells also have a high reliance on sodium pumps to control their intrinsic activity. Partial block of the sodium pumps with ouabain converts the intrinsic tonic pacemaking of Purkinje cells to erratic burst firing. 
In vivo, both Purkinje cells and DCN neurons exhibit abnormal high-frequency burst firing in this model of DYT12. However, how the abnormal bursting cerebellar activity identified in this paper alters activity in other brain regions to induce dystonia remains unknown. Previous research has implicated an aberrant interaction between the cerebellum and basal ganglia in this model of DYT12 dystonia (Calderon et al., 2011). It would be of interest to examine how abnormally bursting cerebellar output alters activity in the basal ganglia and other motor-related areas of the brain.

\section{References}

Alarcón F, Tolosa E, Muñoz E (2001) Focal limb dystonia in a patient with a cerebellar mass. Arch Neurol 58:1125-1127. CrossRef Medline

Albin RL, Young AB, Penney JB (1989) The functional anatomy of basal ganglia disorders. Trends Neurosci 12:366-375. CrossRef Medline

Argyelan M, Carbon M, Niethammer M, Ulug AM, Voss HU, Bressman SB, Dhawan V, Eidelberg D (2009) Cerebellothalamocortical connectivity regulates penetrance in dystonia. J Neurosci 29:9740-9747. CrossRef Medline

Asanuma K, Carbon-Correll M, Eidelberg D (2005) Neuroimaging in human dystonia. J Med Invest 52 [Suppl]:272-279. Medline

Baron MS, Chaniary KD, Rice AC, Shapiro SM (2011) Multi-neuronal recordings in the basal ganglia in normal and dystonic rats. Front Syst Neurosci 5:67. CrossRef Medline

Bean BP (2007) The action potential in mammalian central neurons. Nat Rev Neurosci 8:451-465. CrossRef Medline

Berti V, Pupi A, Mosconi L (2011) PET/CT in diagnosis of movement disorders. Ann N Y Acad Sci 1228:93-108. CrossRef Medline

Bhatia KP, Marsden CD (1994) The behavioural and motor consequences of focal lesions of the basal ganglia in man. Brain 117: 859-876. CrossRef Medline

Blood AJ (2013) Imaging studies in focal dystonias: a systems level approach to studying a systems level disorder. Curr Neuropharmacol 11:3-15. CrossRef Medline

Bragg DC, Armata IA, Nery FC, Breakefield XO, Sharma N (2011) Molecular pathways in dystonia. Neurobiol Dis 42:136-147. CrossRef Medline

Brashear A, Dobyns WB, de Carvalho Aguiar P, Borg M, Frijns CJ, Gollamudi S, Green A, Guimaraes J, Haake BC, Klein C, Linazasoro G, Münchau A, Raymond D, Riley D, Saunders-Pullman R, Tijssen MA, Webb D, Zaremba J, Bressman SB, Ozelius LJ (2007) The phenotypic spectrum of rapid-onset dystonia-parkinsonism (RDP) and mutations in the ATP1A3 gene. Brain 130:828-835. CrossRef Medline

Breakefield XO, Blood AJ, Li Y, Hallett M, Hanson PI, Standaert DG (2008) The pathophysiological basis of dystonias. Nat Rev Neurosci 9:222-234. CrossRef Medline

Brines ML, Gulanski BI, Gilmore-Hebert M, Greene AL, Benz EJ Jr, Robbins RJ (1991) Cytoarchitectural relationships between [3H] ouabain binding and mRNA for isoforms of the sodium pump catalytic subunit in rat brain. Brain Res Mol Brain Res 10:139-150. CrossRef Medline

Brookhart JM, Moruzzi G, Snider RS (1950) Spike discharges of single units in the cerebellar cortex. J Neurophysiol 13:465-486. Medline

Calderon DP, Fremont R, Kraenzlin F, Khodakhah K (2011) The neural substrates of rapid-onset dystonia-parkinsonism. Nat Neurosci 14:357365. CrossRef Medline

Carbon M, Su S, Dhawan V, Raymond D, Bressman S, Eidelberg D (2004) Regional metabolism in primary torsion dystonia: effects of penetrance and genotype. Neurology 62:1384-1390. CrossRef Medline

Carbon M, Raymond D, Ozelius L, Saunders-Pullman R, Frucht S, Dhawan V, Bressman S, Eidelberg D (2013) Metabolic changes in DYT11 myoclonus-dystonia. Neurology 80:385-391. CrossRef Medline

Carter BC, Bean BP (2011) Incomplete inactivation and rapid recovery of voltage-dependent sodium channel during high-frequency firing in cerebellar Purkinje neurons. J Neurophysiol 102:860-871. CrossRef Medline

Carter BC, Bean BP (2009) Sodium entry during action potentials of mammalian neurons: incomplete inactivation and reduced metabolic efficiency in fast-spiking neurons. Neuron 64:898-909. CrossRef Medline

Cooper IS (1976) 20-year followup study of the neurosurgical treatment of dystonia musculorum deformans. Adv Neurol 14:423-452. Medline

Cooper IS, Upton AR, Amin I (1982) Chronic cerebellar stimulation (CCS) and deep brain stimulation (DBS) in involuntary movement disorders. Appl Neurophysiol 45:209-217. Medline

Davis R, Cullen RF Jr, Flitter MA, Duenas D, Engle H, Papazian O, Weis B (1977) Control of spasticity and involuntary movements - cerebellar stimulation. Appl Neurophysiol 40:135-140. Medline

de Carvalho Aguiar P, Sweadner KJ, Penniston JT, Zaremba J, Liu L, Caton M, Linazasoro G, Borg M, Tijssen MA, Bressman SB, Dobyns WB, Brashear A, Ozelius LJ (2004) Mutations in the $\mathrm{Na}+/ \mathrm{K}+-$-ATPase alpha3 gene ATP1A3 are associated with rapid-onset dystonia parkinsonism. Neuron 43:169-175. CrossRef Medline

Dow RS, Moruzzi G (1958) The Physiology and Pathology of the Cerebellum. Minneapolis, MN: University of Minnesota.

Eidelberg D, Moeller JR, Antonini A, Kazumata K, Nakamura T, Dhawan V, Spetsieris P, deLeon D, Bressman SB, Fahn S (1998) Functional brain networks in DYT1 dystonia. Ann Neurol 44:303-312. CrossRef Medline

Fletcher NA, Harding AE, Marsden CD (1990) A genetic study of idiopathic torsion dystonia in the United Kingdom. Brain 113: 379-395. CrossRef Medline

Fraioli B, Guidetti (1975) Effects of stereotactic lesions of the dentate nucleus of the cerebellum in man. Appl Neurophysiol 38:81-90. Medline

Franklin K, Paxinos G (2008) The mouse brain in stereotaxic coordinates. San Diego: Academic.

Gahm NH, Russman BS, Cerciello RL, Fiorentino MR, McGrath DM (1981) Chronic cerebellar stimulation for cerebral palsy: a double-blind study. Neurology 31:87-90. CrossRef Medline

Gauck V, Jaeger D (2000) The control of rate and timing of spikes in the deep cerebellar nuclei by inhibition. J Neurosci 20:3006-3016. Medline

Gauck V, Jaeger D (2003) The contribution of NMDA and AMPA conductances to the control of spiking in neurons of the deep cerebellar nuclei. J Neurosci 23:8109-8118. Medline

Goto S, Kawarai T, Morigaki R, Okita S, Koizumi H, Nagahiro S, Munoz EL, Lee LV, Kaji R (2013) Defects in the striatal neuropeptide Y system in X-linked dystonia-parkinsonism. Brain 136:1555-1567. CrossRef Medline

Guehl D, Cuny E, Ghorayeb I, Michelet T, Bioulac B, Burbaud P (2009) Primate models of dystonia. Prog Neurobiol 87:118-131. CrossRef Medline

Gulledge AT, Dasari S, Onoue K, Stephens EK, Hasse JM, Avesar D (2013) A sodium-pump-mediated afterhyperpolarization in pyramidal neurons. J Neurosci 33:13025-13041. CrossRef Medline

Häusser M, Clark BA (1997) Tonic synaptic inhibition modulates neuronal output pattern and spatiotemporal synaptic integration. Neuron 19:665678. CrossRef Medline

Heinzen EL, Swoboda KJ, Hitomi Y, Gurrieri F, Nicole S, de Vries B, Tiziano FD, Fontaine B, Walley NM, Heavin S, Panagiotakaki E, Panagiotakaki E, Panagiotakaki E, Panagiotakaki E, Fiori S, Abiusi E, Di Pietro L, Sweney MT, Newcomb TM, Viollet L, et al. (2012) De novo mutations in ATP1A3 cause alternating hemiplegia of childhood. Nat Genet 44:10301034. CrossRef Medline

Hieber V, Siegel GJ, Fink DJ, Beaty MW, Mata M (1991) Differential distribution of $(\mathrm{Na}, \mathrm{K})$-ATPase alpha isoforms in the central nervous system. Cell Mol Neurobiol 11:253-262. CrossRef Medline

Holton JL, Schneider SA, Ganesharajah T, Gandhi S, Strand C, Shashidharan P, Barreto J, Wood NW, Lees AJ, Bhatia KP, Revesz T (2008) Neuropathology of primary adult-onset dystonia. Neurology 70:695-699. CrossRef Medline

Hounsgaard J (1979) Pacemaker properties of mammalian Purkinje cells. Acta Physiol Scand 106:91-92. CrossRef Medline

Ito M, Yoshida M, Obata K (1964) Monosynaptic inhibition of the intracerebellar nuclei induced rom the cerebellar cortex. Experientia 20:575576. CrossRef Medline

Jahnsen H (1986) Electrophysiological characteristics of neurones in the guinea-pig deep cerebellar nuclei in vitro. J Physiol 372:129-147. Medline

Jinnah HA, Hess EJ (2006) A new twist on the anatomy of dystonia: the basal ganglia and the cerebellum? Neurology 67:1740-1741. CrossRef Medline

Kirshenbaum GS, Dawson N, Mullins JG, Johnston TH, Drinkhill MJ, Edwards IJ, Fox SH, Pratt JA, Brotchie JM, Roder JC, Clapcote SJ (2013) Alternating hemiplegia of childhood-related neural and behavioural phenotypes in $\mathrm{Na}+, \mathrm{K}+$-ATPase alpha3 missense mutant mice. PloS One 8:e60141. CrossRef Medline

Koch G, Porcacchia P, Ponzo V, Carrillo F, Cáceres-Redondo MT, Brusa L, Desiato MT, Arciprete F, Di Lorenzo F, Pisani A, Caltagirone C, Palomar 
FJ, Mir P (2014) Effects of two weeks of cerebellar theta burst stimulation in cervical dystonia patients. Brain Stimul 7:564-572. CrossRef Medline

Latham A, Paul DH (1971) Spontaneous activity of cerebellar Purkinje cells and their responses to impulses in climbing fibres. J Physiol 213:135-156. Medline

LeDoux MS, Lorden JF (1998) Abnormal cerebellar output in the genetically dystonic rat. Adv Neurol 78:63-78. Medline

LeDoux MS, Lorden JF (2002) Abnormal spontaneous and harmalinestimulated Purkinje cell activity in the awake genetically dystonic rat. Exp Brain Res 145:457-467. CrossRef Medline

LeDoux MS, Lorden JF, Ervin JM (1993) Cerebellectomy eliminates the motor syndrome of the genetically dystonic rat. Exp Neurol 120:302-310. CrossRef Medline

LeDoux MS, Hurst DC, Lorden JF (1998) Single-unit activity of cerebellar nuclear cells in the awake genetically dystonic rat. Neuroscience 86:533545. CrossRef Medline

Llinás R, Mühlethaler M (1988) Electrophysiology of guinea-pig cerebellar nuclear cells in the in vitro brain stem-cerebellar preparation. J Physiol 404:241-258. Medline

Llinás R, Sugimori M (1980) Electrophysiological properties of in vitro Purkinje cell somata in mammalian cerebellar slices. J Physiol 305:171-195. Medline

McGrail KM, Phillips JM, Sweadner KJ (1991) Immunofluorescent localization of three $\mathrm{Na}$, K-ATPase isozymes in the rat central nervous system: both neurons and glia can express more than one Na, K-ATPase. J Neurosci 11:381-391. Medline

Mikati MA, Kramer U, Zupanc ML, Shanahan RJ (2000) Alternating hemiplegia of childhood: clinical manifestations and long-term outcome. Pediatr Neurol 23:134-141. CrossRef Medline

Mouginot D, Gähwiler BH (1995) Characterization of synaptic connections between cortex and deep nuclei of the rat cerebellum in vitro. Neuroscience 64:699-712. CrossRef Medline

Müller U (2009) The monogenic primary dystonias. Brain 132:2005-2025. CrossRef Medline

Nakao M, Gadsby DC (1989) [Na] and [K] dependence of the Na/K pump current-voltage relationship in guinea pig ventricular myocytes. J Gen Physiol 94:539-565. Medline

Oblak AL, Hagen MC, Sweadner KJ, Haq I, Whitlow CT, Maldjian JA, Epperson F, Cook JF, Stacy M, Murrell JR, Ozelius LJ, Brashear A, Ghetti B (2014) Rapid-onset dystonia-parkinsonism associated with the I758S mutation of the ATP1A3 gene: a neuropathologic and neuroanatomical study of four siblings. Acta Neuropathol 128:81-98. CrossRef Medline

Paudel R, Hardy J, Revesz T, Holton JL, Houlden H (2012) Review: genetics and neuropathology of primary pure dystonia. Neuropathol Appl Neurobiol 38:520-534. CrossRef Medline

Peng L, Martin-Vasallo P, Sweadner KJ (1997) Isoforms of Na, K-ATPase $\alpha$ and $\beta$ subunits in the rat cerebellum and in granule cell cultures. J Neurosci 17:3488-3502. Medline

Phukan J, Albanese A, Gasser T, Warner T (2011) Primary dystonia and dystonia-plus syndromes: clinical characteristics, diagnosis, and pathogenesis. Lancet Neurol 10:1074-1085. CrossRef Medline

Pizoli CE, Jinnah HA, Billingsley ML, Hess EJ (2002) Abnormal cerebellar signaling induces dystonia in mice. J Neurosci 22:7825-7833. Medline
Raike RS, Jinnah HA, Hess EJ (2005) Animal models of generalized dystonia. NeuroRx 2:504-512. CrossRef Medline

Raman IM, Bean BP (1997) Resurgent sodium current and action potential formation in dissociated cerebellar Purkinje neurons. J Neurosci 17: 4517-4526. Medline

Raman IM, Gustafson AE, Padgett D (2000) Ionic currents and spontaneous firing in neurons isolated from the cerebellar nuclei. J Neurosci 20 : 9004-9016. Medline

Rosewich H, Thiele H, Ohlenbusch A, Maschke U, Altmüller J, Frommolt P, Zirn B, Ebinger F, Siemes H, Nürnberg P, Brockmann K, Gärtner J (2012) Heterozygous de-novo mutations in ATP1A3 in patients with alternating hemiplegia of childhood: a whole-exome sequencing geneidentification study. Lancet Neurol 11:764-773. CrossRef Medline

Sadnicka A, Hoffland BS, Bhatia KP, van de Warrenburg BP, Edwards MJ (2012) The cerebellum in dystonia-help or hindrance? Clin Neurophysiol 123:65-70. CrossRef Medline

Schmidt A, Klein C (2010) The role of genes in causing dystonia. Eur J Neurol 17 [Suppl 1]:65-70. CrossRef Medline

Schneider SA, Bhatia KP (2010) Secondary dystonia-clinical clues and syndromic associations. Eur J Neurol 17 [Suppl 1]:52-57. CrossRef Medline

Schneider SA, Hardy J, Bhatia KP (2012) Syndromes of neurodegeneration with brain iron accumulation (NBIA): an update on clinical presentations, histological and genetic underpinnings, and treatment considerations. Mov Disord 27:42-53. CrossRef Medline

Sethi KD, Jankovic J (2002) Dystonia in spinocerebellar ataxia type 6. Mov Disord 17:150-153. CrossRef Medline

Stacy MA (2006) Handbook of dystonia. New York: Informa Health Care.

Standaert DG (2011) Update on the pathology of dystonia. Neurobiol Dis 42:148-151. CrossRef Medline

Sweadner KJ (1989) Isozymes of the $\mathrm{Na}+/ \mathrm{K}+$-ATPase. Biochim Biophys Acta 988:185-220. CrossRef Medline

Sweney MT, Silver K, Gerard-Blanluet M, Pedespan JM, Renault F, Arzimanoglou A, Schlesinger-Massart M, Lewelt AJ, Reyna SP, Swoboda KJ (2009) Alternating hemiplegia of childhood: early characteristics and evolution of a neurodevelopmental syndrome. Pediatrics 123:e534-e541. CrossRef Medline

Syková E, Nicholson C (2008) Diffusion in brain extracellular space. Physiol Rev 88:1277-1340. CrossRef Medline

van Gaalen J, Giunti P, van de Warrenburg BP (2011) Movement disorders in spinocerebellar ataxias. Mov Disord 26:792-800. CrossRef Medline

Vidailhet M, Vercueil L, Houeto JL, Krystkowiak P, Benabid AL, Cornu P, Lagrange C, Tézenas du Montcel S, Dormont D, Grand S, Blond S, Detante O, Pillon B, Ardouin C, Agid Y, Destée A, Pollak P, Pollak P (2005) Bilateral deep-brain stimulation of the globus pallidus in primary generalized dystonia. New Engl J Med 352:459-467. CrossRef Medline

Waddy HM, Fletcher NA, Harding AE, Marsden CD (1991) A genetic study of idiopathic focal dystonias. Ann Neurol 29:320-324. CrossRef Medline

Wu YR, Lee-Chen GJ, Lang AE, Chen CM, Lin HY, Chen ST (2004) Dystonia as a presenting sign of spinocerebellar ataxia type 1 . Mov Disord 19:586-587. CrossRef Medline

Zervas NT, Horner FA, Pickren KS (1967) The treatment of dyskinesia by stereotxic dentatectomy. Confin Neurol 29:93-100. CrossRef Medline 